\title{
APLIKASI KEAMANAN PANGAN UNTUK MENINGKATKAN PENGETAHUAN DAN PERILAKU MAKANAN DALAM PENGOLAHAN MAKANAN DI RUMAH SAKIT BOLAANG MONGONDOW
}

\author{
Jufri Sineke ${ }^{1}$, Olga Lieke Paruntu ${ }^{2}$ dan Rudolf B. Purba \\ ${ }^{1,2}$ Nutrition Departement of Manado Ministry of Health Polytechnic \\ Email:jufrisinekegz@gmail.com
}

\begin{abstract}
Backround. The organization of food especially in hospitals must be optimal, in accordance with the quality of health service standard and patient disease indication. The cause of misbehavior regarding hygiene and sanitation is due to low knowledge or ignorance of things that food handlers should be aware of in order to obtain healthy food. The purpose of this research is to know the difference of knowledge and behavior of food safety implementation of food handler on food processing before and after intervention in hospital in Bolaang Mongondow Raya.

Method.The type of research used is Quasi Eksperimen with pretest and posttest design. The research subjects were taken by total sampling totaling 31 people. The study was conducted from July to September 2017 at Bolaang Mongondow Raya Hospital. The knowledge data was collected using questionnaires and behavior data using the check list form. The statistical test used was T-test, at 95\% confidence level and significance limit of $p<0,05$.

Result. The results showed that the average value of knowledge before the intervention was 70.53. Knowledge achievements after the intervention averaged 84.73. The magnitude of the increase in the value of knowledge is 14.2. The average value of the behavior before the intervention is 80.32 . The average value after the intervention was 89.68 . The magnitude of the increase in the value of behavior is 9.36 .

Conclusions. There are differences in knowledge of food handlers before and after the intervention. There are differences in the behavior of food handlers before and after the intervention.
\end{abstract}

Keywords: Food Safety, Food Handler, Hospital

Rumah sakit adalah institusi pelayanan kesehatan yang menyelenggarakan pelayanan kesehatan perorangan secara paripurna serta menyediakan pelayanan rawat inap, rawat jalan, dan gawat darurat (Permenkes RI NOMOR 56/MENKES/PER/2015). Penyelengaraan makanan Rumah Sakit mempunyai kekhususan dimana konsumen dalam keadaan dirawat karena penyakitnya. Oleh karena itu makanan Rumah Sakit harus dapat menunjang bagi kesembuhannya.

Makanan merupakan kebutuhan dasar bagi kelangsungan hidup manusia, sehingga setiap orang perlu dijamin dalam memperoleh pangan yang bermutu dan aman. Bahan makanan yang tidak diproduksi dengan cara yang baik dan benar dapat menjadi sumber mikroorganisme dan kontaminan kimia yang dapat berbahaya dan menyebabkan penyakit kepada manusia. Terjadinya kasus-kasus keracunan 
makanan seharusnya tidak perlu terjadi apabila produk pangan diolah dengan prosedur pengolahan yang benar (Badan POM,2007).

Peranan rumah sakit sebagai penyelenggara dalam pengolahan makanan harus sesuai dengan peraturan yang berlaku, karena makanan yang dikonsumsi oleh pasien maupun pegawai rumah sakit harus memperhatikan keamanan makanan atau food safety yang meliputi aspek hygiene dan sanitasi tempat pengolahan makanan, hygiene personal karyawan, hygiene dan sanitasi peralatan makan dan alat masak, temperatur dan waktu penanganan makanan, penerimaan bahan makanan, penyimpanan bahan makanan, persiapan bahan makanan, dan distribusi makanan.

Menurut Musadad (1995) dalam Iriani menyebutkan perilaku penjamah makanan di rumah sakit, baik secara langsung maupun tidak langsung dapat mempengaruhi kualitas makanan yang disajikan untuk pasien. Betapapun ketatnya peraturan telah dibuat dan dikeluarkan ditambah peralatan kerja dan fasilitas yang memadai, semua akan sia-sia saja bila manusia yang menggunakannya berperilaku yang tidak mendukung seperti pakaian kerja dibiarkan kotor,dan tangan yang dibiarkan tidak bersih. (Depkes,2006). Pemeliharaan higiene dan sanitasi perorangan merupakan kunci dalam pemeliharaan higiene dan sanitasi makanan. Sebagian besar kejadian pencemaran makanan disebabkan oleh tidak terpeliharanya higiene dan sanitasi pekerja yang terlibat dalam proses pengolahan, pemasakan dan penyajian makanan. (Moehyi, 1992)

Food safety di rumah sakit harus sangat diperhatikan karena konsumen dari makanan tersebut merupakan pasien yang sedang dalam tahap pengobatan. Pasien lebih rentan terkontaminasi bakteri dan bahan berbahaya lainnya yang dapat masuk ke dalam tubuh melalui makanan. Apabila makanan pasien terkontaminasi dapat memperpanjang proses perawatan pasien dan dapat menyebabkan timbulnya infeksi silang (cross infection) atau infeksi nosocomial (infeksi yang didapatkan di rumah sakit). Selain itu, food safety di rumah sakit menjadi salah satu poin dalam akreditasi. Akreditasi tersebut mengacu pada standar Komisi Akreditasi Rumah Sakit tahun 2012. Food safety atau keamanan pangan masuk dalam bab pencegahan dan pengendalian infeksi. Dari permasalahan tersebut di atas terdapat peluang untuk melakukan pelatihan food safety agar dapat melaksanakan penyelenggaraan makanan yang baik, sehat dan bergizi bagi pasien di rumah sakit. Pelatihan penerapan food safety dapat meningkatkan pengetahuan dan kesehatan penjamah makanan dan penanggung jawab penyelenggara makanan pasien sehingga dalam jangka panjang menjamin ketersediaan makanan sehat di rumah sakit sesuai kebutuhan gizi pasien. Tujuan Penelitian adalah memberikan pelatihan tentang pemahaman penerapan food safety penjamah makanan pada pengolahan makanan di Rumah Sakit, merekomendasikan penerapan food safety penjamah makanan pada pengolahan makanan di Rumah Sakit, dan mengetahui perbedaan pengetahuan dan perilaku sebelum dan sesudah penerapan food safety penjamah makanan pada pengolahan makanan di Rumah Sakit yang ada di Bolaang Mongondow Raya.

\section{BAHAN DAN CARA}


Jenis penelitian yang digunakan adalah Quasi Eksperimen Pretest and Postest design. Subjek penelitian yang diambil teknik total sampling yaitu semua penjamah makanan berjumlah 31 orang, dan telah memenuhi kriteria sebagai berikut :Penjamah makanan bersedia menjadi responden dengan menandatangani informed consent, penjamah makanan yang bekerja di instalasi gizi dan kooperatif dalam memberikan informasi. Penelitian dilaksanakan pada bulan Juli sampai dengan September 2017, bertempat di Rumah Sakit Umum Daerah Kota Kotamobagu dan Rumah Sakit Umum Monompia Kota Kotamobagu.Variabel yang diukur adalah pengetahuan dan perilaku penjamah makanan tentang penerapan food safety. Metode pengumpulan data adalah wawancara menggunakan kuesioner. Data pengetahuan dikumpulkan menggunakan tes tertulis dalam bentuk pretes dan postes dan observasi perilaku penjamah makanan sebelum dan sesudah pelatihan tentang food safety dimulai dari persiapan bahan makanan sampai pada distribusi makanan. Penilaian pengetahuan dilakukan dengan memberikan skor 1 bila jawaban benar, dan 0 bila salah. Penilaian perilaku penjamah makanan dilakukan dengan memberikan skor 1 bila sesuai benar, dan 0 bila salah. Analisis data univariat (karakteristik dan distribusi frekuensi variabel) untuk mengetahui proporsi/distribusi dan karakteristik subjek penelitian, Hasil analisis dan interpretasi data selanjutnya disajikan dalam bentuk tabel, diagram dan pembahasan yang sesuai dengan realita yang ada. Analisis bivariat dilakukan menggunakan uji comparative untuk mengetahui perbedaan pengetahuan dan perilaku penjamah makanan sebelum dan sesudah intervensi pada masing-masing kelompok menggunakan uji T, pada tingkat kepercayaan 95\% dan batas kemaknaan $p<0,05$.

\section{HASIL}

\section{Karakteristik Subyek Penelitian}

Dari hasil penelitian menunjukkan bahwa sebagian besar (48\%) responden merupakan petugas yang berusia di antara 30 sampai dengan 40 tahun dan terdapat $12,9 \%$ berusia di 50 tahun. Sebagian besar atau $96,7 \%$ berjenis kelamin perempuan, dengan tingkat pendidikan responden adalah 58,07\% SMA sederajat, $29,03 \%$ perguruan tinggi dan $12,90 \%$ Sekolah menengah pertama.

\section{Pengetahuan Penjamah Makanan Sebelum Intervensi}

Capaian pengetahuan penjamah makanan tentang food safety sebelum dilakukan intervensi adalah 19 orang $(61,29 \%)$ berada di atas rata-rata dan masih terdapat 12 orang $(38,71 \%)$ yang masih berada di bawah nilai rata-rata. Nilai ratarata pengetahuan sebelum dilakukan intervensi yang dicapai yaitu 70,53. Gambaran capaian pengetahuan terlihat pada gambar 1 di bawah ini. 


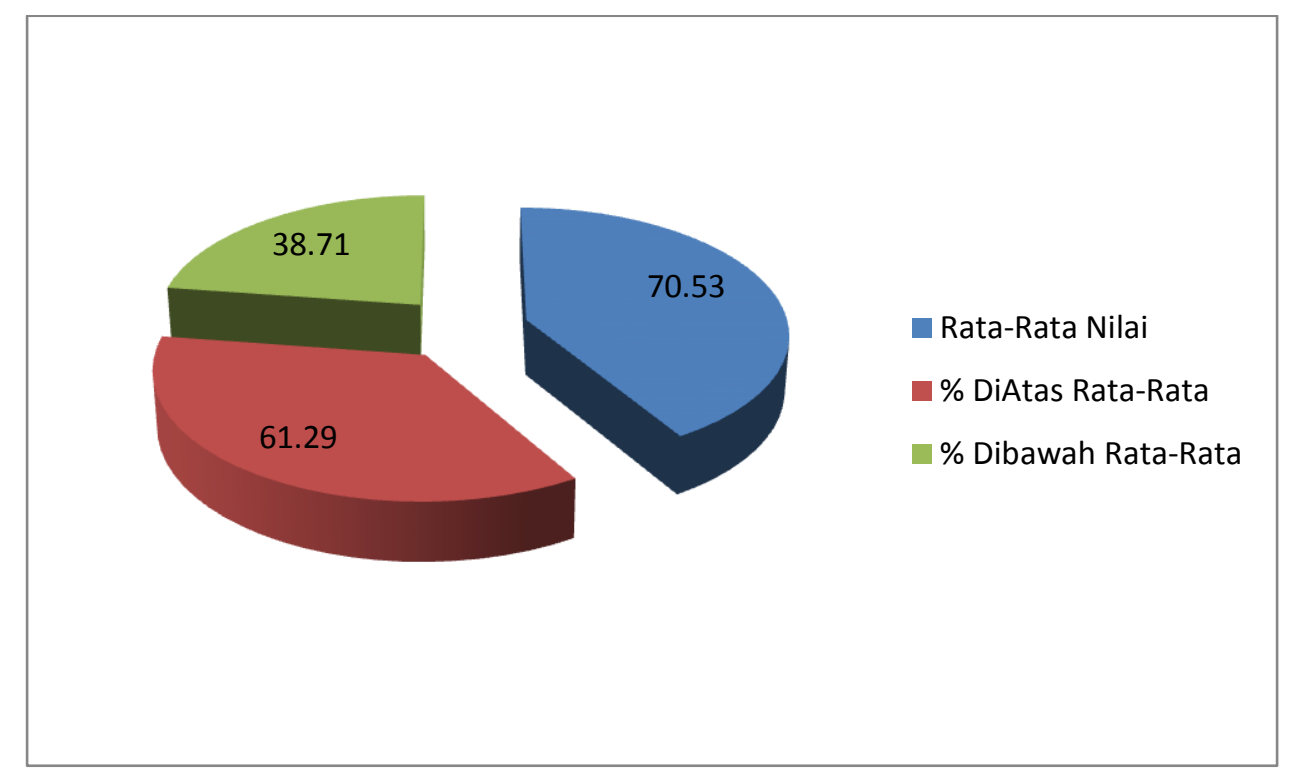

Gambar 1. Pengetahuan sebelum intervensi

\section{Pengetahuan Sesudah Intervensi}

Capaian pengetahuan penjamah makanan tentang food safety sesudah dilakukan intervensi memiliki rata-rata nilai pengetahuan sebesar 84,73 , dan terdapat 21 orang $(67,74 \%)$ berada di atas rata-rata nilai pengetahuan dan terdapat 9 orang $(32,26 \%)$ yang memiliki nilai pengetahuan di bawah rata-rata nilai pengetahuan. Gambaran capaian pengetahuan penjamah makanan sesudah dilakukan intervensi seperti terlihat pada gambar 2 di bawah ini.

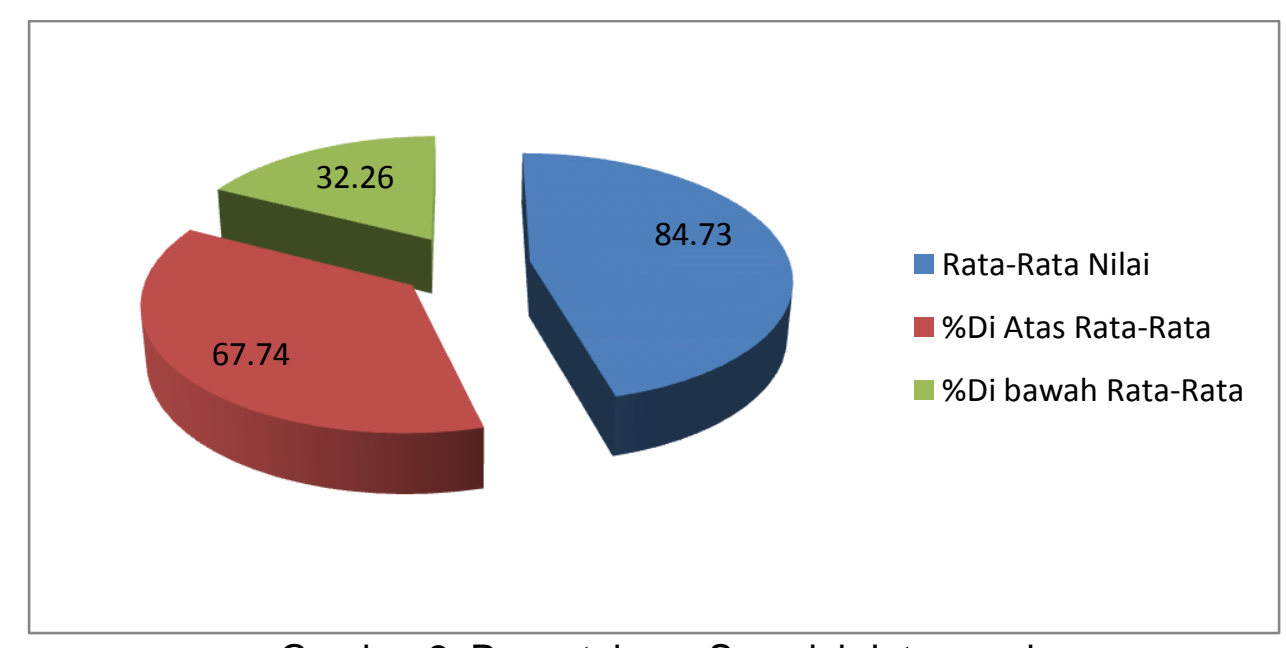

Gambar 2. Pengetahuan Sesudah Intervensi

\section{Besaran Nilai Peningkatan Pengetahuan}


Besaran nilai peningkatan pengetahuan yang dicapai oleh penjamah makanan dapat diketahui dengan melihat selisih rata-rata nilai sebelum dan sesudah dilakukan intervensi. Rata-rata nilai pengetahuan sebelum intervensi sebesar 70,53 dan rata-rata nilai pengetahuan sesudah intervensi adalah 84,73. Hasil ini menujukkan bahwa terjadinya peningkatan nilai pengetahuan penjamah makanan sebesar 14,20 sesudah dilakukan inervensi. Seperti terlihat pada gambar 3.

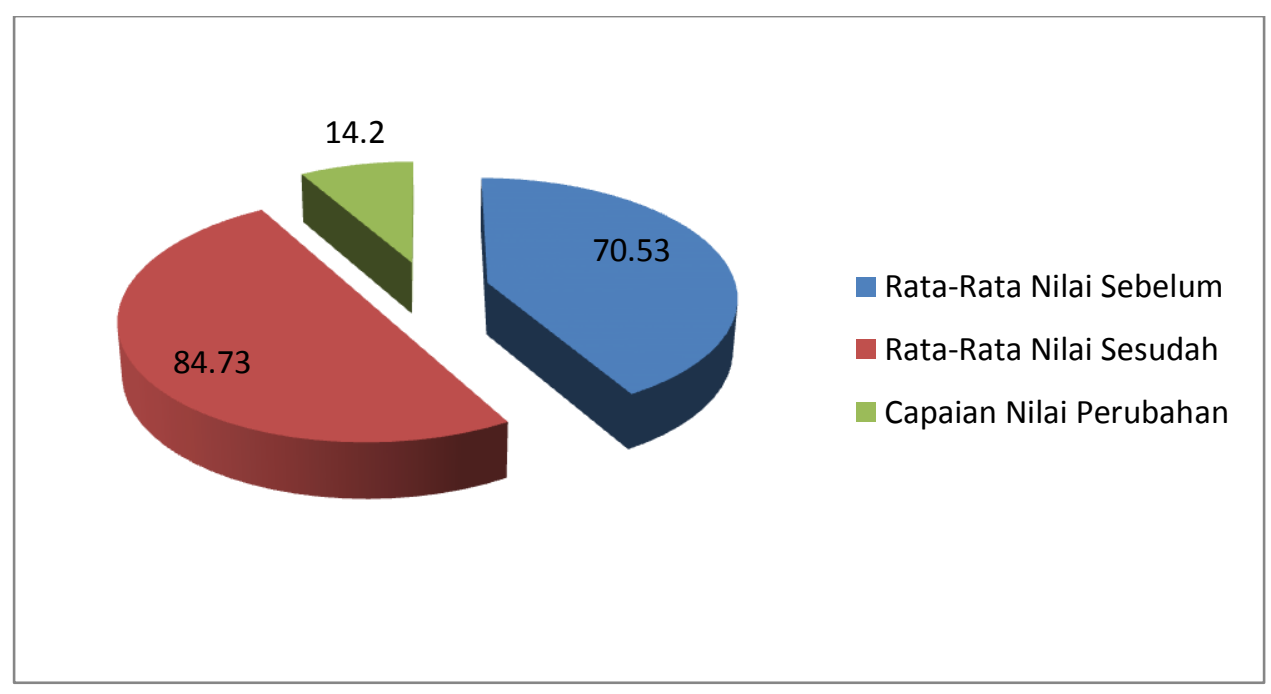

Gambar 3. Capaian Nilai Peningkatan Pengetahuan

Berdasarkan hasil uji statistik ditemukan adanya perbedaan bermakna pengetahuan penjamah makanan sebelum dan sesudah intervensi dimana $p=$ $0.000(p<0,05)$.

\section{Perilaku Hygiene Sanitasi Penjamah Makanan}

Berdasarkan hasil penilaian terhadap perilaku penjamah makanan maka didapat hasil sebagai berikut.:

\section{a. Perilaku Sebelum Intervensi}

Perilaku penjamah makanan tentang hygiene sanitasi dalam rangka penerapan food safety sebelum dilakukan intervensi terdapat 8 orang $(25,81 \%)$ berada di atas rata-rata nilai dan 23 orang (74,19\%) memiliki nilai di bawah ratarata nilai yang dicapai yaitu 80,32 . 


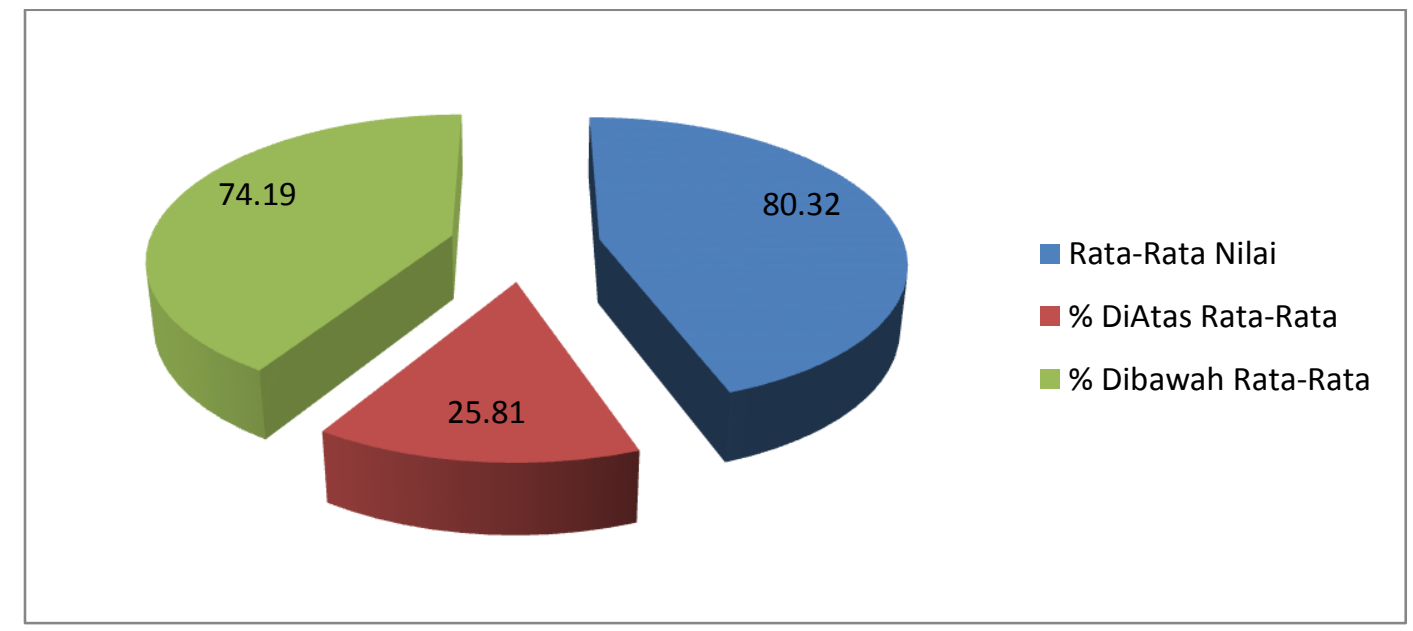

Gambar 4. Perilaku sebelum Intervensi

\section{b. Perilaku Sesudah Intervensi}

Perilaku penjamah makanan tentang hygiene sanitasi dalam rangka penerapan food safety sesudah dilakukan intervensi terdapat 28 orang $(90,32 \%)$ berada di atas nilai rata-rata dan hanya 3 orang $(9,68 \%)$ yang mempunyai nilai di bawah rata-rata nilai yang dicapai yaitu 89,68 . Gambaran perilaku penjamah makanan seperti terlihat pada gambar 5 .

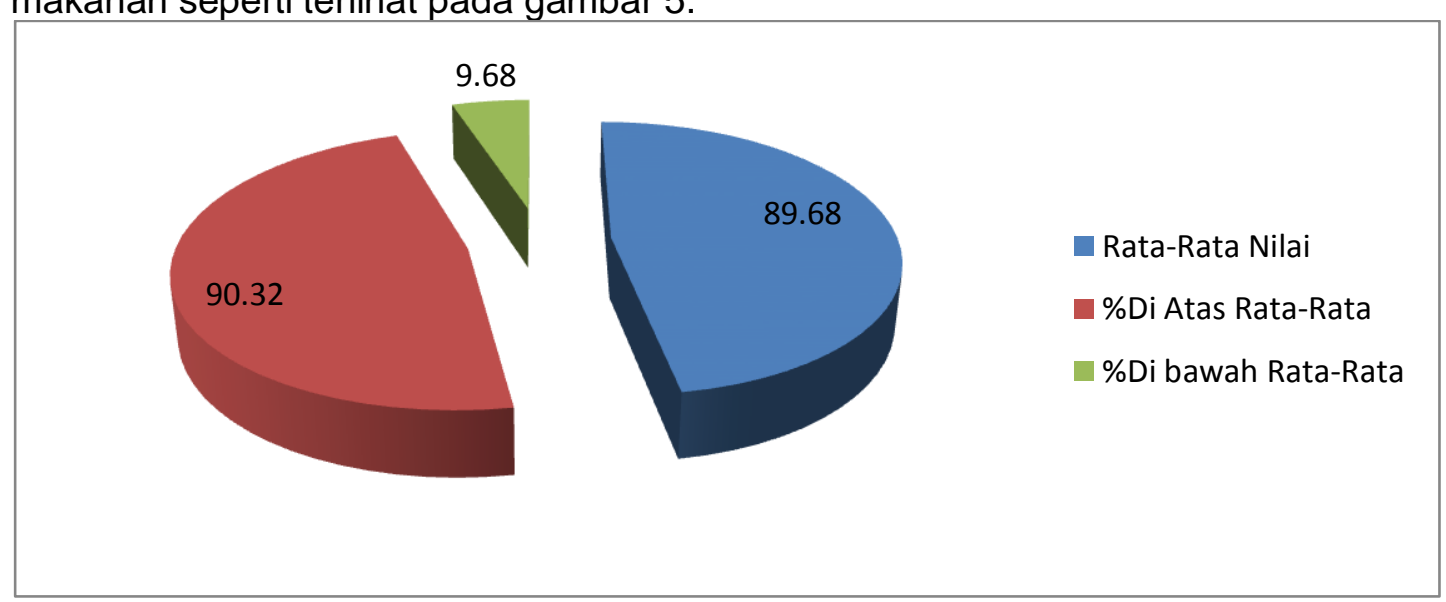

\section{Gambar 5. Perilaku Sesudah Intervensi}

\section{c. Besaran Nilai Peningkatan Perilaku}

Besaran nilai peningkatan perilaku penjamah makanan dapat diketahui dengan melihat selisih rata-rata nilai sebelum dan sesudah dilakukan intervensi. Rata-rata nilai perilaku sebelum intervensi sebesar 80,32 dan rata-rata nilai perilaku sesudah intervensi adalah 89,68 . Peningkatan nilai perilaku penjamah makanan sebesar 9,36 sesudah dilakukan inervensi seperti terlihat pada gambar 6 . 

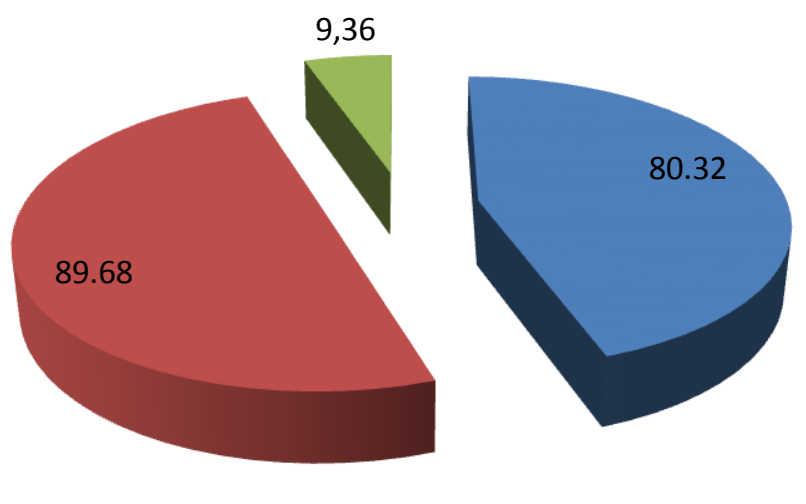

Rata-Rata Nilai Sebelum

Rata-Rata Nilai Sesudah

- Capaian Nilai Perubahan

Gambar 6. Capaian Peningkatan Nilai Perilaku

Berdasarkan hasil uji statistik ditemukan adanya perbedaan antara perilaku penjamah makanan sebelum dan sesudah intervensi dimana $p=0,000 \quad(p<0,05)$.

\section{PEMBAHASAN}

\section{Pengetahuan tentang Keamanan Makanan (Food Safety)}

Bedasarkan hasil penelitian menunjukkan bahwa pengetahuan penjamah makanan sebelum intervensi rata-rata nilai pengetahuan adalah 70,53 dan setelah intervensi mengalami peningkatan menjadi 84,73. Besarnya nilai peningkatan pengetahuan penjamah makanan setelah intervesi 14,20. Hasil uji statistik menunjukkan adanya perbedaan yang bermakna pengetahuan sebelum dan sesudah intervensi. Terjadinya peningkatan pengetahuan dimungkinkan karena tingkat pendidikan penjamah makanan $87,09 \%$ adalah pendidikan SMA dan perguruan tinggi.

Menurut Notoatmodjo (2007), pengetahuan adalah hasil pengindraan manusia atau hasil tahu seseorang terhadap objek melalui indra yang dimiliki dan salah satu faktor yang mempengaruhi pengetahuan seseorang yaitu pendidikan. Pengetahuan sangat erat kaitannya dengan pendidikan, dan makin tinggi pendidikan, maka orang tersebut akan semakin luas pula pengetahuannya. Namun perlu ditekankan bahwa seorang yang berpendidikan rendah tidak berarti mutlak berpengetahuan rendah pula. Bila dilihat hasil penelitian yang ditemukan menunjukkan bahwa pengetahuan penjamah makanan sebelum dilakukan intervensi terdapat $38,53 \%$ berada di bawah rata-rata nilai 70,53 , dan bila dibandingkan dengan pengukuran pengetahuan oleh Arikunto (2006) masih termasuk kategori pengetahuan cukup.

Hasil penelitian yang dilakukan Andiniwati (2008) di Instalasi Gizi rumah sakit Karyadi dan rumah sakit Ketilang Semarang, menemukan bahwa tingkat pengetahuan pegawai lebih dari $50 \%$ berpengetahuan kurang tentang hygiene sanitasi dalam penyelenggaraan makanan. Penelitian Iriani (2000) di Instalasi Gizi RSU DAM Bandar Lampung menemukan sebanyak 50\% penjamah makanan berpengetahuan kurang tentang hygiene perorangan, dan selanjutnya dijelaskan 
bahwa masih kurangnya pengetahuan tenaga pengolah makanan tentang hygiene dalam pengolahan makanan dalam penelitian ini, dikarenakan masih terdapat tenaga pengolah makanan $(28,6 \%)$ yang berpendidikan rendah yaitu tamat SD dan SMP, disamping itu masih banyaknya tenaga pengolah makanan $(83,3 \%)$ yang belum pernah mendapat kursus atau penyuluhan tentang hygiene dan sanitasi makanan atau penyuluhan belum diberikan secara rutin sehingga belum dapat menimbulkan kesadaran dalam diri responden untuk melakukan praktek yang baik.

Tuntutan jaminan keamanan makanan terus berkembang sesuai dengan persyaratan konsumen yang terus meningkat dan seirama dengan kenaikan kualitas hidup manusia. Hal ini menjadikan masalah keamanan makanan menjadi sangat vital bagi industri dan bisnis pangan. Food safety diartikan sebagai kondisi dan upaya yang diperlukan untuk mencegah makanan dari kemungkinan cemaran biologis, kimia dan benda lain yang dapat mengganggu, merugikan dan membahayakan kesehatan manusia serta tidak bertentangan dengan agama, keyakinan, dan budaya masyarakat sehingga aman untuk dikonsumsi (UU RI No 18/2012). Pelaksanaan food safety yang baik dapat mencegah terjadinya bahaya dari mulai penerimaan bahan makanan hingga penyajian makanan kepada konsumen.

Menurut Adams (2004), penjamah makanan diartikan sebagai orang yang pekerjaannya menyiapkan bahan makanan hingga siap untuk dikonsumsi. Penjamah makanan merupakan salah satu dari pihak yang berperan dalam keamanan pangan selain pengambil keputusan, produsen, pengelola dan konsumen pangan. Pada usaha tata boga baik di katering maupun di instalasi gizi rumah sakit, penjamah makanan adalah ujung tombak penyelenggaraan pangan. Seperti dikemukakan oleh Tamaroh (2002), faktor yang terpenting pada keamanan pangan adalah penjamah makanan. Penjamah makanan yang berpendidikan rendah akan melaksanakan tugasnya hanya mengandalkan kebiasaan yang dimilikinya tanpa mengetahui alasan yang benar yang melatarbelakangi tindakannya. Berdasarkan hasil penelitian menunjukkan bahwa sebagian besar atau 58,07\% penjamah makanan berpendidikan SMA dan 29,03\% tamat perguruan tinggi.

\section{Perilaku Hygiene Penjamah Makanan}

Perilaku hygiene merupakan salah satu faktor yang paling penting yang harus dimiliki oleh tenaga pengolah makanan, bedasarkan hasil observasi menunjukkan bahwa perilaku penjamah makanan sebelum intervensi rata-rata nilai adalah 80,32 dan setelah intervensi mengalami peningkatan menjadi 89,68. Besarnya nilai peningkatan perilaku penjamah makanan setelah intervesi 9,68. Hasil uji statistik menunjukkan adanya perbedaan yang bermakna perilaku sebelum dan sesudah intervensi. Terjadinya peningkatan perilaku dimungkinkan karena tingkat pendidikan penjamah makanan $87,09 \%$ adalah pendidikan SMA dan perguruan tinggi, juga tingkat pengetahuan penjamah makanan setelah intervensi $67,74 \%$ memiliki nilai di atas rata-rata nilai 84,73, yang dalam kateori pengetahuan baik.

Pengetahuan akan menimbulkan kesadaran dan akhirnya akan menyebabkan orang berperilaku sesuai dengan pengetahuan yang dimiliki, dan penambahan pengetahuan tidak bisa hanya dalam waktu singkat tetapi harus terus menerus dan berkelanjutan, juga memberikan informasi-informasi baru, sehingga 
pengetahuan terus bertambah dan mendalam, karena dengan menkristalisasi terhadap seseorang untuk berperilaku baik, pengetahuan akan tetap menjadi kontrol (Notoatmojo, 2005).

Perilaku penjamah makanan di rumah sakit, baik secara langsung maupun tidak langsung dapat mempengaruhi kualitas makanan yang disajikan untuk pasien. Pemeliharaan higiene dan sanitasi perorangan merupakan kunci dalam pemeliharaan higiene dan sanitasi makanan. Perilaku penjamah makanan yang tidak mendukung tentunya akan menimbulkan masalah terhadap keamanan pangan. Sebagaimana hasil penelitian, Afriani menyatakan bahwa lemahnya personal hygiene dapat mengakibatkan kontaminasi terhadap makanan dan lainnya. Hal ini didasarkan pada hasil observasi di RSUD Kota Kotamobagu dan RSU Monompia yang menunjukkan masih adanya perilaku hygiene penjamah makanan yang perlu ditingkatkan dalam hal penggunaan tutup kepala, tidak berbicara saat mengolah makanan dan menggunakan alas kaki tertutup dengan hak yang rendah. Hasil penelitian yang dilakukan oleh Ellyani,A, (2010) menyatakan bahwa dalam pengolahan makanan penjamah makanan kurang memperhatikan cara kerja yang hygiene, terlihat bahwa seluruh tenaga penjamah makanan tidak mencuci tangan dengan sabun sebelum bekerja, menyentuh makanan dengan jari, berbicara pada saat bekerja, serta tidak menggunakan pakaian kerja (celemek).

Menurut Peraturan Menteri Kesehatan Republik Indonesia No 1096/Menkes/PER/VI/2011, keadaan perorangan yang perlu diperhatikan penjamah makanan dalam hal ini tenaga pengolah makanan untuk mencegah penularan penyakit dan kontaminasi mikroba pathogen melalui makanan adalah antara lain tidak merokok, tidak makan dan mengunyah, tidak memakai perhiasan, kecuali cincin kawin yang tidak berhias (polos), selalu mencuci tangan sebelum bekerja, setelah bekerja dan keluar dari toilet, selalu memakai pakaian kerja dan pakaian pelindung dengan benar dan bersih yang tidak dipakai diluar tempat kerja serta tidak banyak berbicara dan menggunakan penutup mulut (masker) saat mengolah makanan.

Makanan yang memenuhi syarat tidak hanya sekedar memenuhi syarat gizi, menarik, rasanya enak, kelunakannya sesuai, akan tetapi juga harus bebas dari berbagai mikroorganisme yang dapat membuat makanan menjadi rusak atau busuk atau dapat menghasilkan zat yang berbahaya bagi kesehatan manusia. Kerusakan pada makanan atau bahan makanan yang terjadi dapat dilihat dari adanya perubahan bau, perubahan rasa, perubahan warna atau perubahan kelunakan makanan atau bahan makanan itu. Akan tetapi ada juga makanan yang tercemar ataupun rusak yang tidak memperlihatkan perubahan tersebut. Terjadinya pencemaran dapat dikarenakan oleh berbagai sumber seperti air yang digunakan tidak memenuhi syarat kesehatan, makanan yang diletakkan di tempat terbuka sehingga tercemar kuman melalui udara atau lalat, adanya serangga akibat kebersihan yang kurang dijaga lingkungan dapurnya, dan yang paling sering adalah akibat makanan yang dijamah oleh tangan (Moehyi, 1999).

\section{KESIMPULAN}

Terjadi peningkatan pengetahuan penjamah makanan sebesar 14,20 setelah dilakukan intervensi.Terjadi peningkatan perilaku hygiene penjamah makanan 
sebesar 9,36 seteleh dilakukan intervensi. Terdapat perbedaan pengetahuan tenaga penjamah sebelum dan sesudah dilakukan intervensi. Terdapat perbedaan perilaku tenaga penjamah makanan sebelum dan sesudah dilakukan intervensi. Salah satu kegiatan dari penyehatan makanan di rumah sakit menekankan pada tersedianya makanan yang berkualitas baik dan aman bagi kesehatan konsumen, menurunnya kejadian risiko penularan penyakit atau gangguan kesehatan melalui makanan, serta terwujudnya perilaku kerja yang sehat dan benar dalam penanganan makanan. Instalasi gizi selaku pelaksana penyelenggaraan makanan di rumah sakit diharapkan menggunakan pedoman Pelayanan Gizi Rumah Sakit. Juga Perlu peningkatan pengetahuan dan perilaku hygiene bagi penjamah makanan melalui pelatihan atau kursus sanitasi hygiene makanan di rumah sakit.

\section{DAFTAR PUSTAKA}

Adams, M, Motarjemi, Y. Dasar-Dasar Keamanan Makanan untuk Petugas Kesehatan. Jakarta: EGC; 2004.

Arikunto. S, 2006. Prosedur Penelitian Suatu Pendekatan Praktek, Edisi Revisi. Jakarta : PT. Rineka Cipta. Jakarta

Badan POM, 2007. Cara Produksi Pangan yang Baik II. Modul Pelatihan Pengawas Pangan Tingkat Muda. IPB. Bogor.

Departemen Kesehatan RI, 2006. Keputusan menteri kesehatan RI tentang persyaratan hygiene sanitasi jasa boga. Jakarta :Depkes RI.

Ellyani, Abadi, 2010. Tinjauan Sanitasi dan Hygiene dalam Sistem Penyelenggaraan Makanan di Rumah Sakit Umum Daerah Abunawas Kendari. Jurnal.

Iriani, Fitrizal, 2000, Faktor-faktor Yang Berhubungan Dengan Perilaku Higiene Perorangan Pada Penjamah Makanan di Instalasi Gizi RSUD Dr.H. Abdul Moeloek Bandar lampung. Skripsi FKM UI, Jakarta.

Kementerian Kesehatan RI, 2015. Pedoman Pelayanan Gizi Rumah Sakit.

Krisnamurni,S. Keamanan Pangan Pada Penyelenggaraan Makanan di Rumah Sakit, Makalah Disampaikan pada pertemuan ilmiah nasional Asosiasi Dietisien Indonesia ke III di Semarang, 19 - 21 Juli 2007.

Moehyi, Sjahmien. 1992. Penyelenggaraan Makanan Institusi dan Jasa Boga. Penerbit Bhratara, Jakarta.

Moehji, Sjahmien. 1999. IImu Gizi. Penerbit Bhratara, Jakarta.

Mulyani, Rosa. 2013. Pengetahuan, Sikap dan Perilaku Hygiene Pengolah Makanan di Instalasi Gizi RSUDAM Propinsi Lampung. Jurnal.

Notoatmodjo, S. 2007. Kesehatan Masyarakat IImu dan Seni. Jakarta: Pt. Rineke

Cipta.

Notoatmodjo, 2005. Metodologi Penelitian Kesehatan. Edisi Revisi Cetakkan ke

Tiga. Jakarta : Rineka Cipta.

Suwandi Sontang, 2012. Jaminan Mutu dalam Indsutri Pangan. Artikel http//suwandihan.wordpress.com

Tamaroh S., 2003. Knowledge, Practices and Attitude on Food safety of Food handlers in Catering Establishmen in Yogjakarta, Seminar Nasional PAPTI 30

- 31 Juli 2002, Malang. 